\title{
Audit Committee Characteristics and Earnings Management: The Case of Bahrain
}

\author{
Omar Juhmani \\ Professor, Accounting Department, University of Bahrain \\ PO Box 32038, Sakher, Bahrain \\ Email: ojuhmani@uob.edu.bh
}

Received: December 12, 2016 Accepted: December 30, 2016 Published: January 28, 2017

doi:10.5296/ijafr.v7i1.10447 URL: http://dx.doi.org/10.5296/ijafr.v7i1.10447

\begin{abstract}
This study examines the effectiveness of some audit committee (AC) characteristics to monitor management behavior with the respect to their incentives to manage earnings. Bahraini listed companies on Bahrain Bursa for the year 2012 to 2014 have been investigated to analyze the relationship between $\mathrm{AC}$ characteristics and earnings management. The $\mathrm{AC}$ characteristics examined are $\mathrm{AC}$ independence, $\mathrm{AC}$ size, $\mathrm{AC}$ meetings and $\mathrm{AC}$ financial experts. Multivariate regression model is used to examine the relationship between earnings management as dependent variable and $\mathrm{AC}$ characteristics as independent variables and other firm-specific attributes, as control variables. As a small developing market, Bahrain's unique business environment and context offer a good opportunity and provides a useful setting for examining the effectiveness of AC characteristics in detecting and preventing earnings management practices. The results show that discretionary accruals as a proxy for earnings management is negatively associated with $\mathrm{AC}$ size and $\mathrm{AC}$ financial experts, but positively associated audit firm size as control variable. However, the results do not show a significant relationship between AC independence, AC meetings, company size, leverage and earnings management. This study extends the literature on the monitoring function of the AC on earnings management, and contributes geographically to the financial reporting process and earnings management literatures by analyzing data from an emerging market and providing useful information for the corporations, accounting profession and the regulators on the effective practice of ACs.
\end{abstract}

Keywords: Audit committee characteristics, Earnings management, Bahrain 


\section{Introduction}

Corporate scandals such as WorldCom, Enron, Nortel, eToys and similar others, put the spotlight on the effectiveness of corporate governance mechanisms in monitoring the financial reporting process. AC is considered as one of the crucial and influential participants of corporate governance as it assists the board of directors in discharging its responsibilities in overseeing corporate management (Bédard and Gendron, 2010; Li et al., 2012). An AC is a sub-committee of the board that specializes in, and is responsible for, ensuring the accuracy and reliability of the financial statements provided by management. Indeed, much of the blame and criticism for accounting irregularities is aimed at ACs for not fulfilling their financial reporting oversight duties due to independence issues (Pergola, 2005). The effectiveness of ACs has been a subject of increasing interests due to increased concerns about the quality of corporate financial reporting process caused by recent accounting scandals. Therefore, the Sarbanes-Oxley Act (2002) in the U.S. mandates the role of the AC and strengthens its composition to oversee the financial reporting process.

Managers are using earnings management to maximize company's interest or to maximize their own interest. A frequently used description of earnings management is given by Healy and Wahlen (1999) "Earnings management occurs when managers use judgment in financial reporting and in structuring transactions to alter financial reports to either mislead some stakeholders about the underlying economic performance of the company or to influence contractual outcomes that depend on reported accounting numbers". Since earnings management is inherently unobservable, most studies used measures of accruals as proxies for earnings management. The central objective of CGC is to restore the reliability of financial statements by curbing earnings management and accounting fraud (Cohen et al., 2008). Therefore, on the process to restore the confidence to the investors, different laws and codes were puts in place, for example, Sarbanes-Oxley Act (2002) in US and Corporate Governance Codes by many countries. In Bahrain the first CGC has been effective on $1^{\text {st }}$ January 2011. All Bahraini companies to which this Code applies should be in full compliance by the end of 2011. The Bahrain CGC is expected to mitigate corporate scandals and other related issues. The Bahrain CGC stated that, the board shall establish an AC of at least three members of which the majority should be independent including the chairman. The AC shall review the company's accounting and financial practices, review the integrity of the company's financial and internal controls and financial statements, review the company's compliance with legal requirements, and recommend the appointment, compensation and oversight of the company's outside auditor. Also, the code recommends a majority of the AC members should have the financial literacy qualifications.

There has been growing recognition in recent years of the importance of AC in enhancing financial reporting quality. However the relationship between AC characteristics and earnings management, remains unexplored in emerging markets. In addition, there is a shortage of studies that target the Gulf Cooperation Council (GCC) countries. Given the importance of $\mathrm{AC}$ characteristics in enhancing the quality of financial reporting in the region, this study focuses on one of the GCC countries, namely Bahrain. Bahrain is one of the most open economies in the MENA region and it is one of the world's leading international financial 
centers. The Bahrain Stock Exchange, which officially commenced operations in 1989, has grown significantly in the number of listed securities with currently 49 companies (Baena, 2011). Royal Decree No. 60 was issued regarding the establishment of Bahrain Bourse to replace Bahrain Stock Exchange. This step has been taken to bring in line the bourse's capability to meet the modern administrative requirements of international exchanges, as well as the commercial standards that are deemed necessary to meet the rapid developments witnessed in modern stock exchanges. During 2010, Bahrain Bourse joined the Association of National Numbering Agencies (Bahrain Bourse, 2010).

As a small developing market, Bahrain's unique business environment and context offer a good opportunity and provides a useful setting for examining the association between ACs and earnings management. Therefore, this study extends the literature on the monitoring function of the $\mathrm{AC}$ on earnings management, and contributes geographically to the financial reporting process and earnings management literatures by analyzing data from an emerging market and providing useful information for the corporations, researchers, accounting profession and the regulators on the effective practice of ACs. The main purpose of this study is to examine the relationship between AC characteristics and discretionary accruals as proxy for earnings management in Bahrain.

The remainder of this study is organized as follows. Section two presents a review of the literature and the development of hypotheses. Section three explains the research methodology employed in this study. The empirical findings are presented in section four. Finally, section five summarizes the main conclusions of the study.

\section{Literature Review and Hypotheses Development}

\subsection{Literature Review}

Managers are using earnings management to maximize company's interest (shareholders interest) or to maximize their own interest, this causes an agency problem. However, both have different interests and this leads to conflicts (Jensen, 2005 and Leuz et al., 2003). Fama and Jensen (1983) have argued that outside directors with directorships are perceived to be valuable because they are concerned about their reputation damage, litigation risks and possible loss of future board opportunities and therefore will be motivated to perform their monitoring role effectively. Laing and Weir (1999) have argued that the AC is responsible for the external auditing of the firm financial statements. Due to the existence of remuneration and ACs monitor of board performance, it is expected that board will be motivated to improve performance, and investors will gain more confidence in the value of firm's financial statement.

Researchers have identified the role of the AC as being critical in ensuring credibility of the financial statement (e. g. Fama and Jensen, 1983, Abbott, et al., 2000). Therefore, the AC is viewed as a monitoring mechanism intended to reduce information asymmetries between management and stakeholders, since its key functions are to improve the quality and accuracy of financial information through constantly monitoring the management's opportunistic behaviours (e.g., Klein, 2002; Davidson et al., 2005; Pucheta-Martinez and Fuentes, 2007; . 


\section{Macrothink \\ International Journal of Accounting and Financial Reporting \\ ISSN 2162-3082 \\ 2017, Vol. 7, No. 1}

Dhaliwal et al., 2010; Li et al., 2012).

The effectiveness of ACs has been a subject of increasing interests due to increased concerns about the quality of corporate financial reporting process caused by accounting scandals. Dechow and Skinner (2000) note that the border between earnings management and accrual accounting has become ambiguous. It deals with managers choosing accounting policies and accruals, most likely for personal gain. Therefore, managers can opportunistically manipulate accounting reports by managing accruals. However, Kaplan (1985) state that "normal" accruals arising in the ordinary course of business are unlikely to reflect managerial opportunistic behavior. Any manipulation of accounting information will most likely be apparent in "abnormal" accruals.

Literature on AC has suggested that AC effectiveness essentially functions on AC characteristics (e. g. Persons, 2009; Bédard and Gendron, 2010; Dhaliwal et al., 2010; Li et al., 2012). Therefore, the perfect AC size with the right combination of skills and experience are critical in supporting the AC's ability in detecting and preventing earnings management. Several research studies have investigated the relation between AC characteristics and discretionary accruals as a proxy for earnings management. For example, Xie et al. (2003) found that accrual-based earnings management is less likely to occur or is less prevalent in the companies whose ACs include greater proportion of independent members with corporate or investment banking background. Previous studies suggested that firms with the higher number of AC meetings experience are less likely to be sanctioned for fraud as well as aggressive accounting (Abbott et al., 2000). Prior research provides evidence suggesting that $\mathrm{AC}$ size and the financial expertise of AC members can have a significant effect on the monitoring of earnings management, the empirical evidence also supports the advantages of including independent directors on the AC (e.g., Klein, 2002; Pucheta-Martinez and Fuentes, 2007).

\subsection{Hypotheses}

In the light of the empirical and the theoretical literature framework, I have found a series of relationships, which other authors also previously found, between AC characteristics and the level of earnings management. Accordingly, the following hypotheses are developed to investigate the effect of $\mathrm{AC}$ characteristics, namely, $\mathrm{AC}$ independence, $\mathrm{AC}$ size, the frequency of $\mathrm{AC}$ meetings, and $\mathrm{AC}$ expertise on earnings management practices in Bahrain.

\subsubsection{Audit Committee Independence}

The Sarbanes-Oxley Act of (2002) emphasizes the importance of the independence of the AC for effective monitoring of financial reporting, and requires all $\mathrm{AC}$ members to be independent. Klein, (2002) argues that AC independence influences the effectiveness of the committee in monitoring financial reporting. Prior literature argues that less financial misstatements are associated with more independent audit committees (e.g. Abbott et al. 2000). Also, prior literature suggested that a fully independent AC would be better able to protect shareholders' interests and fulfill its monitoring role because of its ability to view issues objectively (e.g., Bédard et al., 2004; Abbott, et al. 2004; Yang and Krishnan, 2005). 


\section{MInstitute Macrothink $_{\text {Int }}$}

International Journal of Accounting and Financial Reporting ISSN 2162-3082 2017, Vol. 7, No. 1

It is generally believed that an independent AC provides effective monitoring of the financial discretion exercised by management and ensures the credibility of the financial statements. In this regard Deli and Gillan (2000) argued that an audit committee serves as a reinforcing agent to the independence of internal as well as external auditor, audit committees are expected to be more effective in the oversight of financial reporting when they are independent. Also, Xie et al., (2003) suggested that the more independent audit committee will provide better governance compared to less independent AC. These arguments, suggestions and expectations are supported by the provision in Sarbanes-Oxley Act requiring publicly traded companies to have completely independent ACs. In Bahrain, the Bahrain CGC stated that, the board shall establish an AC of at least three members of which the majority should be independent including the chairman.

The literature provides mixed results on the association between AC independence and the levels of earnings management. For example, Klein (2002) in USA, Xie et al. (2003) in USA, Davidson, et al. (2005) in Australia, Lin and Hwang (2010) and Soliman and Ragab (2014) in Egypt reported a negative association between ACs' independence and earnings management practices. Bédard, et al. (2004) in USA found that aggressive earnings management is negatively associated with fully independent ACs. Abbott et al., (2004) found that there is a negative association between $\mathrm{AC}$ independence and financial reporting fraud and misstatement. Fodio et al. (2013) found that AC independence has a positive association with earnings management. However, Abdul Rahman and Ali (2006) in Malaysia, Lin et al., (2006) in the USA, Siregar and Utama (2008) in Indonesia, Habbash (2011) in Saudi Arabia and Waweru and Riro (2013) in Nairobi found an insignificant relationship between ACs' independence and earnings management.

Regulations, agency theory, and the governance literature suggest a negative association between the independence of the AC and earnings management. Therefore, and despite the inconsistent findings in the literature reported above, this study proposes a negative association between the independence of the AC and earnings management.

\section{H1: The audit committee independence is negatively associated with earning management.}

\subsubsection{Audit Committee Size}

Menon and Williams (1994) argued that an AC with less than three members is likely to be ineffective. The Blue Ribbon Committee (1999), in its ten recommendations submitted on the $\mathrm{AC}$, recommended that an effective $\mathrm{AC}$ of listed companies should comprise at least three directors. According to Abbott et al. (2004) and Xie et al. (2003) the perfect average of the AC size is between 3 and 4 members. Vafeas (2005) argued that, if the AC size is too small then an insufficient number of directors to serve the committee in occurring and thus decrease its monitoring effectiveness. This perhaps because small committee is not capable of fulfilling its duties efficiently, and when a committee size is too large, the directors' performance may decline because of the coordination and process problems and hence highlight another reason for weak monitoring (Jensen, 1993; Vafeas, 2005). 


\section{Ml Macrothink}

International Journal of Accounting and Financial Reporting ISSN 2162-3082 2017, Vol. 7, No. 1

The literature suggested that the firms with large AC are more effective in monitoring the management, and it may play a vital role in constraining the occurrence of earnings management. The literature provides mixed results on the association between AC size and earnings management. For example, Yang and Krishnan (2005), Lin et al., (2006), Baxter and Cotter (2009), Lin and Hwang (2010) and Fodio et al. (2013) found a negative significant association between the size of ACs and earnings management. However, Xie et al. (2003), Bédard et al. (2004), Abbott et al. (2004), Hussain Alkdai (2012) and Soliman and Ragab (2014) found no significant relationship between audit committees size and the level of earnings management. Despite the inconsistent findings in the literature reported above, this study proposes a negative association between the size of the $\mathrm{AC}$ and earnings management.

\section{H2: The audit committee size is negatively associated with earning management.}

\subsubsection{Audit Committee Meetings}

Lin and Hwang (2010) suggest that, an important objective of the AC is to provide its members with sufficient time to perform their duties of monitoring their firm's financial reporting process. Karamanou and Vafeas (2005) suggest that, AC that meets more frequently is more likely to effectively accomplish its monitoring role. Li et al. (2012) suggest that, an active $\mathrm{AC}$ that meets frequently during the year, would provide its members with greater opportunities for discussing and evaluating the issues placed before them concerning the company's financial reporting practices. Xie et al., (2003) suggest that, ACs that meet regularly during the financial year are associated with effective monitoring.

Also, Klein (2002) suggests that an active AC as measured by the number of meetings are positively associated with AC independence, also he suggests that AC independence influences the effectiveness of the committee in monitoring financial reporting. Accordingly it is generally agreed that $\mathrm{AC}$ that meets more frequently is more likely to effectively detecting and preventing earnings management practices.

The literature provides mixed results on the association between AC meetings and earnings management. For example, Abbott et al., (2000) found a negative association between meeting frequency and the occurrence fraudulent financial reporting. Abbott et al. (2004) found ACs that meet at least four times per year demonstrate a significant and negative association with the occurrence of financial reporting restatements. Also, Xie et al. (2003), Abdul Rahman and Ali (2006), Lin and Hwang (2010), Metawee (2013) and Soliman and Ragab (2014) found a significant negative association between AC meetings and earnings management practices. However, Bédard et al., (2004), Davidson et al. (2005) and Lin et al., (2006) found no significant relationship between ACs meetings and the level of earnings management. Despite the inconsistent findings in the literature reported above, this study proposes a negative association between the frequency of $\mathrm{AC}$ meetings and earnings management.

H3: The frequency of audit committee meetings is negatively associated with earning management. 


\section{Macrothink \\ International Journal of Accounting and Financial Reporting \\ ISSN 2162-3082 \\ 2017, Vol. 7, No. 1}

\subsubsection{Audit committee expertise}

The Sarbanes-Oxley Act of (2002) mandates that at least one member of the AC must be a financial expert. In Bahrain, the Bahrain CGC stated that, a majority of the AC should have the financial literacy qualifications. Financial expertise leads AC members to identify and ask knowledgeable questions that challenge management and external audit to a greater extent of financial reporting quality (Bédard and Gendron, 2010). It is generally agreed that the key duty of the $\mathrm{AC}$ is to review the financial reporting process to ensure the best quality of financial reports, thus the availability of an accounting and financial expertise in the AC would enhance its efficiency and its ability in detecting and preventing earnings management. The literature reveals that the effectiveness of the $\mathrm{AC}$ is enhanced through the presence of financial experts on the committee (Naiker and Sharma, 2009; Dhaliwal et al., 2010).

The findings of the most of prior researches support the negative association between AC expertise and earnings management. For example, Bédard et al. (2004) found that financial expertise is associated with a significant decrease in aggressive earnings management, Abbott et al. (2004) found a significantly negative association between an AC having at least one member with financial expertise and the incidence of financial restatement, and they found that the financial expertise of the $\mathrm{AC}$ is related with a higher financial reporting quality. Nelson and Devi (2013) examined the association of AC experts with financial reporting quality, proxied by earnings management, they found the presence of non-accounting experts and accounting experts is significant to reduce the magnitude of earnings management. Sharma and Kuang, (2014) found that financial expertise is associated with a lower likelihood of aggressive earnings management but only when the expertise is held by independent directors. Xie et al. (2003), Choi et al., (2004), Lin and Hwang (2010) and Soliman and Ragab (2014) found that earnings management is negatively associated with AC member's expertise. Accordingly, this study proposes a negative association between the AC expertise and earnings management.

\section{H4: The audit committee expertise is negatively associated with earning management.}

\subsection{Control Variables}

This study includes three variables to control for other factors influencing management's incentives to manage or manipulate reported earnings. This study control for company size and proposes a negative association between company size and earnings management because larger firms are likely to have more effective internal control systems and face more scrutiny from the market (Dechow et al. 1995; Bédard et al., 2004). Also, it is expected that small companies are more likely motivated to engage in earnings management practices to cover their higher marginal cost comparing with large companies that enjoy the benefit from economies of scale (Lin et al. 2009). Previous studies found a negative relation between company size and earnings management (e. g Xie et al., 2003; Abdul Rahman and Ali, 2006; Nelson and Devi, 2013; Sharma and Kuang, 2014). Also, this study control for leverage and proposes a positive association between leverage and earnings management, it is expected that companies that have high leverage suffer from excessive risk, consequently these companies are more likely manipulated their earning (Watts and Zimmerman, 1986; Dechow 


\section{Mll Macrothink}

International Journal of Accounting and Financial Reporting

ISSN 2162-3082

2017, Vol. 7, No. 1

et al. 1995). The literature provides mixed results on the association between leverage and earnings management. For example, Park and Shin (2004) and Nelson and Devi (2013) reported a negative association, Bédard et al. (2004) and Sharma and Kuang (2014) reported a positive association, while, Lin et al. (2006) found no significant association between leverage and earnings management.

This study also control for the size of audit firm. Empirical evidence supports that Big4 auditors are better at constraining client earnings management compared to non-Big4 auditors (Francis et al. 1999; Krishnan, 2003). Zhou and Elder (2003) and Chen et al. (2005) found that Big 4 auditors associated with less earnings management practices. Therefore, this study proposes a negative association between the size of audit firm and earnings management among Bahraini listed companies.

\section{Methodology}

\subsection{Study Sample, Data Collection and Data Analysis}

The initial study sample includes all Bahraini companies listed on the Bahrain Bourse (BB) for the period from 2012 to 2014, all listed companies are included due to the relatively small number of companies listed on BB. The selection of study period takes into account the most recent data available when this study started, also, this selection takes into account the three years data available after implementing the first CGC in Bahrain. The total number of Bahraini companies listed in BB in 2014 is 42 companies make up the initial sample for this study. However, due to suspension and incomplete financial data, 11 companies were excluded from the analyses. Therefore, the final number of companies included in the analyses is 31 Bahraini companies and 95 firm-year observations.

The data for measuring the dependent and independent variables investigated in this study were collected from the sampled companies' annual reports that were downloaded from the official website of the BB and Bahraini companies. The data is analyzed through the use of descriptive statistics, bivariate correlation and linear regression analysis.

\subsection{The Dependent Variable (Earnings Management)}

A widely accepted measure of earnings management (dependent variable) is discretionary accruals (Kothari et al., 2005). Most of previous studies used various measures of discretionary accruals as proxies for earnings management. The most popular measures to calculate discretionary accruals are the Jones and modified-Jones models (Dechow et al., 1995; Beneish and Press, 1998; Bartov et al., 2000). However, based on prior literatures, it was observed that the modified-Jones model is the most famous and the most frequently used model to detecting discretionary accruals. Thus it was adopted in this study to estimate discretionary accruals, which is specified as follows, 


\section{Macrothink}

$$
\left.\left.\left.\mathrm{TAC}_{i t} / \mathrm{A}_{i t-1}=\beta_{1}\left(^{1 / \mathrm{A}_{i t-1}}\right)+\beta_{2} \square \square \mathrm{REV}_{i t}-\Delta \mathrm{REC}_{i t}\right) / \mathrm{A}_{i t-1}\right]+\beta_{3} \square \mathrm{PPE}_{i t} / \mathrm{A}_{i t-1}\right)+\varepsilon_{i t}(1)
$$

where:

$\mathrm{TAC}_{i t}=$ total accruals for firm $i$ in the current year $t$;

$\mathrm{A}_{i t-1}=$ total assets for firm $i$ at the end of the previous year;

$\Delta^{\mathrm{REV}_{i t}}=$ change in revenue for firm $i$ between the current year and previous

year;

$\Delta \mathrm{REC}_{i t}=$ the change in receivables for firm $i$ between the current year

and previous year;

$\mathrm{PPE}_{i t}=$ gross property, plant and equipment for firm $i$ in the current year;

Using the cash flow approach (Hribar and Collins, 2002), total accruals (TAC) are calculated as the difference between operating income (OI) obtained from the income statement and operating cash flows (OCFO) obtained from the statement of cash flows.

$\mathrm{TAC}_{i t} \square-\mathrm{OI}_{i t} \square-\mathrm{OCFO}_{i t}$

The predicted values from equation (1) are non-discretionary accruals (NDAC), and the difference between actual total accruals (TAC) and (NDAC) is discretionary accruals (DAC) (Kothari et al., 2005).

$\mathrm{DAC}_{i t} \square \square \mathrm{TAC}_{i t} \square-\mathrm{NDAC}_{i t}$

\subsection{Measurement of the Independent Variables}

The independent variables used in this study are AC characteristics, namely, AC independence, $\mathrm{AC}$ size, $\mathrm{AC}$ meetings, and $\mathrm{AC}$ financial expertise. Consistent with prior research, the four AC variables are identified and measured as shown in Table 1.

\subsection{Measurement of the control variables}

In order to test the association between earnings management and $\mathrm{AC}$ characteristics, and to mitigate the potential bias resulting from firm's operation on earnings management and to capture firm's operational characters, three control variables are added to the regression model namely, company size, leverage, and audit firm size. The control variables were 


\section{Macrothink

measured as shown in Table 1.

\subsection{Regression Model Development}

In order to examine the effect of each independent variable and each control variable on the dependent variable the following multivariate regression model is executed in this study.

$E M=\beta_{0}+\beta_{1} A D C M I N D+\beta_{2} A D C M S I Z E+\beta_{3} A D C M M E E T+\beta_{4} A D C M E X P$

$+\beta_{5} \operatorname{COSIZE}+\beta_{6} L E V G+\beta_{7}$ AUDFSIZE $+\epsilon$

where:

EM = Earnings management;

$A D C M I N D=$ Audit committee independence;

ADCMSIZE = Audit committee size;

ADCMMEET = Audit committee meetings;

ADCMEXP = audit committee financial experts;

COSIZE = Company size;

LEVG = Leverage;

AUDFSIZE = Audit firm size;

$\epsilon=$ error term. 
Table 1: Variables Definitions and Measurements

Variables

Definitions and Measurements

\section{Dependent variable}

$\mathrm{EM}$

Independent variables

Earnings management, measured by discretionary accruals as a proxy.

ADCMIND

ADCMSIZE

Audit committee size, number of members on the audit committee;

ADCMMEET

Audit committee meetings, number of audit committee meetings held during the fiscal year;

ADCMEXP

Audit committee financial experts, the percentage of audit committee members having expertise in accounting or financial management.

\section{Control variables}

COSIZE

Company size, the companies' natural log of total assets;

LEVG

Leverage, measured as the ratio of the companies' total liabilities to the companies' total assets.

AUDFSIZE

Audit firm size, a dummy variable that equals 1 if the company is audited by Big- 4 auditor and 0 otherwise;

\section{Results}

The descriptive statistical test results of all variables for the sample of companies are presented in Table 2, the results show that, the average earnings management (EM) is 0.727 . The average percentage of independent (non-executive) directors on the audit committee (ADCMIND) is $85.98 \%$ with a minimum value of $25 \%$. The average number of members on the audit committee (ADCMSIZE) is 3.78 with a minimum of 2 and maximum of 7 members. The average number of AC meetings held during the fiscal year (ADCMMEET) is 4.47 with a minimum of 2 and maximum of 8 meetings. On average, 74.42\% of AC members possess financial or accounting experts (ADCMEXP) with a minimum value of $16.66 \%$. Also, the 


\section{Al Macrothink \\ International Journal of Accounting and Financial Reporting ISSN 2162-3082}

descriptive statistical test results in Table 2 show that, company size (COSIZE) on average is 19.24 of it is natural logarithm value. The average leverage ratio (LEVG) is 0.427. Most Bahraini listed companies (76\%) are audited by Big-4 auditors (AUDFSIZE).

Table 2: Descriptive Statistics

Variables

Minimum Maximum Mean

Std. Deviation

\begin{tabular}{lllll}
\hline EM & -0.9094 & 5.0791 & 0.7275 & 1.020 \\
ADCMIND & 0.25 & 1 & 0.8598 & 0.2322 \\
ADCMSIZE & 2 & 7 & 3.78 & 1.113 \\
ADCMMEET & 2 & 8 & 4.47 & 1.119 \\
ADCMEXP & 0.1666 & 1 & 0.7442 & 0.2354 \\
COSIZE & 15.88 & 23.25 & 19.24 & 2.010 \\
LEVG & 0.0019 & 1.7055 & 0.4270 & 0.3271 \\
AUDFSIZE & 0 & 1 & 0.76 & 0.431 \\
\hline
\end{tabular}

The variables are defined in Table 1. 


\section{1) Macrothink}

Table 3: Pearson Correlations

EM 1

$\begin{array}{lccccccc}\text { ADCMIND } & .144 & 1 & & & & \\ & .163 & & & & & \\ \text { ADCMSIZE } & -.068- & -.084- & 1 & & & \\ & .512 & .417 & & & & \\ \text { ADCMMEET } & .164 & -.131- & .051 & 1 & & \\ & .113 & .204 & .625 & & & & \\ \text { ADCMEXP } & -.144- & .060 & -.251^{*} & -.116- & 1 & & \\ & .163 & .566 & .014 & .263 & & & \\ \text { COSIZE } & .199 & .183 & .311^{* *} & .139 & -.046- & 1 \\ & .053 & .075 & .002 & .180 & .656 & & \\ \text { LEVG } & .164 & .074 & -.056- & .141 & -.017- & .467^{* *} & 1 \\ & .112 & .473 & .589 & .171 & .869 & .000 & \\ \text { AUDFSIZE } & .143 & .047 & .398^{* *} & .086 & .012 & .106 & -.008- \\ & .168 & .651 & .000 & .407 & .906 & .305 & .940\end{array}$

*. Correlation is significant at the 0.05 level (2-tailed).

**. Correlation is significant at the 0.01 level (2-tailed).

The Pearson correlation coefficients between dependent and independent variables are presented in Table 3. The results show that there is a moderately high correlation between some variables. However, it has been suggested that correlation coefficients should not be considered harmful until they exceed 0.80 (Judge et al., 1985). The coefficients in the correlation matrix in Table 3 reveal that the highest correlation is (.467) between company size and leverage, which support the lack of multicollinearity in the regression model. In addition, another more formal method for detecting multicollinearity involves the calculation of the variance inflation factor (VIF). VIF measures the degree to which each explanatory variable is explained by the other explanatory variables and very large VIF values indicate high collinearity and a common cutoff threshold is VIF values above 10 (Hair, et al. 1995). The VIF figures of all independent variables are calculated and presented in Table 4, the results show that the highest VIF value is 1.6 indicating that multicollinearity did not exist in the regression model.

The results in table 4 indicate that the multiple regression model is highly significant, which statistically supports the significance of the model. The results in table 4 show a significant negative association at the 5\% level between discretionary accruals as a proxy for earnings management and AC size. This finding supports Hypothesis 2, and suggests that, higher AC size is associated with a significant decrease in earnings management among Bahraini listed 


\section{MInstitute Macrothink $_{\text {Int }}$}

International Journal of Accounting and Financial Reporting ISSN 2162-3082

companies. This result confirms the assumption that, size is a very important attribute of the effective ACs and can have a significant effect on the monitoring of earnings management (e.g. Pincus et al., 1989). Also, this result supports the argument that, if the AC size is too small then an insufficient number of directors to serve the committee in occurring and thus decrease its monitoring effectiveness (Vafeas, 2005), and, it confirms the assumption that, having a sufficient number of AC members increases the efficiency of its monitoring function in terms of financial reporting integrity (Baxter and Cotter, 2009).

Also, the descriptive statistical test results in Table 2 revealed a perfect average AC size (i e. 3.78) among Bahraini listed companies. This result confirms the assumption that, the perfect average of the AC size is between 3 and 4 members (Abbott et al., 2004; Xie et al., 2003), and it confirms the assumption that small committee is not capable of fulfilling its duties efficiently as the given assignments is always increasing. Also, when a committee size is too large, the directors' performance may decline because of the coordination and process problems and hence highlight another reason for weak monitoring (Jensen, 1993; Vafeas, 2005). Empirical research generally supports these claims and assumptions. AC size is found to be negatively associated with earning management (e. g. Yang and Krishnan, 2005; Lin et al., 2009; Baxter and Cotter, 2009; Lin and Hwang, 2010; Fodio et al., 2013).

The results in Table 4 also show that there is a significant negative association at the $10 \%$ level between earnings management and AC financial experts. This finding supports Hypothesis 4, and suggests that higher level of AC financial expertise is associated with a significant decrease in earnings management among Bahraini listed companies. This result supports the argument that, the audit committee's financial expertise increases the likelihood that detected material misstatements will be communicated to the AC and corrected in a timely fashion (DeZoort and Salterio, 2001). Empirical research generally supports these arguments and suggestions. AC financial expertise is found to be associated with a significant decrease in earnings management (e. g. Xie et al., 2003; Abbott et al., 2004; Choi et al., 2004; Bédard et al., 2004; Lin et al., 2009; Lin and Hwang, 2010; Nelson and Devi, 2013; Soliman and Ragab, 2014; Sharma and Kuang, 2014).

$\mathrm{AC}$ independence and $\mathrm{AC}$ meetings variables can play active role in reducing earnings management. However, the results of the regression model show that neither variable has a significant association with the level of earnings management. Accordingly, the first and third hypotheses are rejected. This finding is consistent with Lin et al., (2006), Abdul Rahman and Ali (2006) and Waweru and Riro (2013) who found that independence of the audit committee is not significantly associated with earnings management, also this finding is consistent with Bédard et al., (2004), Davidson et al. (2005), and Lin et al., (2006), Baxter and Cotter (2009), and Lin et al., (2009) who found that number of AC meetings is not significantly associated with earnings management. 


\section{Mll Macrothink \\ International Journal of Accounting and Financial Reporting \\ ISSN 2162-3082 2017, Vol. 7, No. 1}

Table 4: The Results of the Regression Model and VIF Values

\begin{tabular}{lcc}
\hline \multicolumn{3}{c}{ Dependent Variable } \\
\hline & Earnings Management (EM) & \\
\hline Independent Variables & Model & VIF \\
\hline Constant & $(-.971)$ &
\end{tabular}

\section{Audit Committee variables}

$\begin{array}{lll} & .101 & 1.077 \\ \text { ADCMIND } & (.974) & \\ \text { ADCMSIZE } & -.259 & 1.543 \\ & (-2.111) * * & \\ \text { ADCMMEET } & .117 & 1.106 \\ & (1.145) & 1.102 \\ \text { ADCMEXP } & -.195 & \\ & (-1.876)^{*} & \\ \text { Control variables } & & 1.60 \\ \text { COSIZE } & .199 & \\ & (1.594) & 1.373 \\ \text { LEVG } & .031 & \\ & (.271) & 1.233 \\ \text { AUDFSIZE } & .212 & \\ & (1.938)^{* *} & \\ R \text {-Square } & 0.154 & \\ \text { Adjusted } R \text {-Square } & 0.086 & \\ F \text {-statistic } & 2.269 & \\ \text { Prob (F-statistic) } & 0.036 & \\ \text { Obs } & 95 & \end{array}$

The variables are defined in Table 1.

$t$-values in parentheses.

* Significant at the 0.10 level (2-tailed).

** Significant at the 0.05 level (2-tailed).

The results in Table 4 show that, company size and leverage as a control variables are not associated with earnings management, these results may suggest that, both small and large companies with different levels of financial leverage are likely tend to engage earnings management practices. However, the results of the regression model show that, there is a significant positive association at the 5\% level between earnings management and audit firm size. This finding suggests that Bahraini companies audited by large auditing firms associated with high earnings management practices. This result along with the result of insignificant association between AC independence and earnings management reported above, support the assumption that, much of the blame and criticism for accounting irregularities is aimed at ACs for not fulfilling their financial reporting oversight duties due to independence issues 
(Pergola, 2005), also it support Deli and Gillan (2000) who argued that, an audit committee serves as a reinforcing agent to the independence of internal as well as external auditor, audit committees are expected to be more effective in the oversight of financial reporting when they are independent, and these results support Xie et al., (2003) who suggested that, the more independent audit committee will provide better governance compared to less independent $\mathrm{AC}$.

\section{Conclusion}

Recent corporate scandals put the spotlight on the effectiveness of AC in detecting material misstatements thus reducing the likelihood of earnings management. This study provides the first evidence on the relation between ACs and earnings management in Bahrain. Specifically, the study examines the association between earnings management and the following $\mathrm{AC}$ characteristics: independence of the $\mathrm{AC}$; size of the $\mathrm{AC}$; frequency of $\mathrm{AC}$ meetings; and expertise of the AC. To achieve the objectives of this study, the annual reports of all Bahraini listed companies for the period 2012-2014 were analyzed.

The results of the regression model show that, there is a significant negative association between discretionary accruals as a proxy for earnings management and AC size. Also, the results show a significant negative association between earnings management and AC financial experts. These findings suggest that, the level of earnings management of Bahraini listed companies is decreased with the increase in the number of members on the ACs. Also it suggest that, the level of earnings management of Bahraini listed companies is decreased with the increase in the percentage of AC members having expertise in accounting or financial management. These results are consistent with the assumptions that, a larger AC is better able to ensure the quality and integrity of reported earnings, and AC's financial or accounting expertise increases the likelihood of detecting material misstatements thus reducing the likelihood of earnings management.

Also, results of the regression model show positive association between earnings management and audit firm size. This finding suggests that Bahraini companies audited by large auditing firms associated with high earnings management practices. This result along with the result of insignificant association between AC independence and earnings management, support the assumption that, much of the blame and criticism for accounting irregularities is aimed at ACs for not fulfilling their financial reporting oversight duties due to independence issues, also it support the argument that, an audit committee serves as a reinforcing agent to the independence of internal as well as external auditor, audit committees are expected to be more effective in the oversight of financial reporting when they are independent, and it support the suggestion that, the more independent audit committee will provide better governance compared to less independent AC. These findings, arguments and suggestions are supported by the provision in Sarbanes-Oxley Act requiring publicly traded companies to have completely independent ACs.

This study offers several contributions. First, it provides new evidence on the relation between AC characteristics and the level of earnings management. Second, it provides new evidence on the effectiveness of the $\mathrm{AC}$ independence to curb the level of earnings 
management. Third, it may help in studying other stock markets in the GCC countries, which may contribute to the accounting literature on emerging markets. The findings of this study can serve as a benchmark for studies in countries with an institutional and economic environment similar to Bahrain. This study is not free from limitations. It uses a small sample of Bahraini listed companies. Although the study can contribute to the understanding of the relationship between ACs and earnings management in Bahrain, it may not be able to be generalized to other countries. Such relationships could be different from country to country due to business and legal environments; therefore, there is a need to examine these relationships among different countries.

\section{Acknowledgement}

This research is financed by the deanship of scientific research at University of Bahrain.

\section{References}

Abbott, L. J., Park, Y. and Parker, S. (2000). The effects of audit committee activity and independence on corporate fraud, Managerial Finance, 26 (11), 55-67.

Abbott, L., Parker, S. and Peters, G. (2004). Audit committee characteristics and restatements, Auditing: A Journal of Practice \& Theory 23, 69-87.

Abdul Rahman, R., and Ali, F. H. M., (2006). Board, Audit Committee, Culture and Earnings Management: Malaysian evidence, Managerial Auditing Journal, 21(7), 783 - 804.

Baena, V. (2011). The effect of corruption on global franchising in emerging markets", International Journal of Business and Emerging Markets, 3(1), 57-74.

Bartov, E., Gul, F. A., and Tsui, J. S. L. (2000). Discretionary-accruals models and audit qualifications, Journal of Accounting and Economics, 30(3), 421-452.

Baxter, P., and Cotter, J. (2009). Audit committees and earnings quality. Accounting and Finance, 49(1), 267-290.

Bédard, J., Chtourou, S. and Courteau, L. (2004). The effect of audit committee expertise, independence, and activity on aggressive earnings management, Auditing: A Journal of Practice \& Theory, 23(2), 13-35.

Bédard, J., and Gendron, Y. Y. (2010). Strengthening the financial reporting system: Can audit committees deliver?, International Journal of Auditing, 14(2),174-210.

Beneish, M. D., and Press, E. (1998). Discussion of 'Are accruals during initial public offering opportunistic? , Review of Accounting Studies, 3(1/2), 209-221.

Blue Ribbon Committee (BRC) (1999). Report and recommendations of the Blue Robin Committee on improving the effectiveness of corporate audit committees, New York: New York Stock Exchange and National Association of Securities Dealers. 


\section{$\triangle$ Macrothink}

International Journal of Accounting and Financial Reporting ISSN 2162-3082

Chen, Y. M., Moroney, R. and Houghton, K. (2005). Audit committee composition and the use of an industry specialist audit firm. Accounting and Finance, 45(2), 217-239.

Choi, J., Jeon, K. and Park, J. (2004). The role of audit committees in decreasing earnings statement: Korean evidence, International Journal of Accounting, Auditing \& Performance Evaluation, 1(1), 37-60.

Cohen, D. A., Dey, A., and Lys, T. Z. (2008). Real and accrual-based earnings management in the pre- and post-Sarbanes-Oxley periods, The Accounting Review, 83(3), 757-787.

Davidson, R., Goodwin-Stewart, J. and Kent, P. (2005). Internal governance structures and earnings management, Accounting \& Finance, 45(2), 241-267.

Dechow, P. and Skinner D. (2000). Earnings Management: Reconciling the Views of Accounting Academics, Practitioners, and Regulators, Accounting Horizons, 14 (2), 235-250.

Dechow, P. M., Sloan, R. G. and Sweeney, A. P. (1995). Detecting earnings management, The Accounting Review, 70(2), 193-225.

Deli, D. N., and Gillan, S. L. (2000). On the demand for independent and active audit committees, Journal of Corporate Finance, 6, 427-455.

DeZoort, F.T. and Salterio, S.E. (2001). The effects of corporate governance experience and financial reporting and audit knowledge on audit committee member judgments, Auditing: A Journal of Practice \& Theory, 20(1), 31-47.

Dhaliwal, D., Naiker, V., and Navissi, F. (2010). The Association Between Accruals Quality and the Characteristics of Accounting Experts and Mix of Expertise on Audit Committees, Contemporary Accounting Research, 27(3), 787-827.

Fodio, M. I., Ibikunle, J., and Oba, V. C. (2013). Corporate governance mechanisms and reported earnings quality in listed Nigerian insurance firms. International Journal of Finance and Accounting, 2(5), 279-286.

Fama, E.F. and Jensen, M.C., (1983). Separation of ownership and control, Journal of Law and Economics, 26(2), 301-325.

Francis, J., Maydew, L.E., and Sparks, H.C. (1999). The Role of Big 6 Auditors in The Credible Reporting of Accruals. Auditing: A Journal of Practice \& Theory, 18(2), 17-34.

Hair, J.F. Anderson, R.E. Tatham, R.L. Black, W.C. (1995). Multivariate data analysis with readings, Prentice-Hall, New York.

Healy, P. M. \& Wahlen, J. M. (1999). A review of the earnings management literature and its implications for standard setting, Accounting Horizons, 13 (4), 365-83.

Hribar, P. and Collins, D. W. (2002). Errors in estimating accruals: Implications for empirical research, Journal of Accounting Research, 40(1), 105-134.

Hussain Alkdai, H. K. (2012). Audit committee characteristics and earnings management Malaysian Shariah-compliant companies. Business and Management Review, 2(2), 52-61. 


\section{Macrothink}

International Journal of Accounting and Financial Reporting ISSN 2162-3082

Jensen, M. C. (1993). The modern industrial revolution, exit, and the failure of internal control systems, The Journal of Finance, 48(3), 831-80.

Jensen, M. C. (2005), Agency Costs of Overvalued Equity, Financial Management, 34(1), 519.

Judge, G. G., Griffiths, W. E., Hill, R. C., Lutkepohl, H. and Lee, T. (1985). The Theory and Practice of Econometrics, $2^{\text {nd }}$ ed., New York: John Wiley \& Sons.

Kaplan. R. S. (1985). Comments on Paul Healy: Evidence on the Effect of Bonus Schemes on Accounting Procedure and Accrual Decisions, Journal of Accounting and Economics, 7, 109-113.

Karamanou, I. and Vafeas, N. (2005). The association between boards and audit committees with management earnings forecasts: An empirical analysis. Journal of Accounting Research, 43(3): 453-486.

Klein, A. (2002). Audit committee, board of director characteristics, and earnings management, Journal of Accounting and Economics, 33(3), 375-400.

Kothari, S. P., Leone, A. J. and Wasley, C. E. (2005). Performance matched discretionary accrual measures, Journal of Accounting \& Economics, 39(1), 163-197.

Krishnan, G.V. (2003). Audit Quality and The Pricing of Discretionary Accruals. Auditing: A Journal of Practice \& Theory, 22(1), 109-126.

Li, J., Mangena, M., and Pike, R., (2012). The Effect of Audit Committee Characteristics on Intellectual Capital Disclosure, British Accounting Review, 44 (2), 98-110.

Laing, D. and Weir, C. (1999). Governance structures, size and corporate performance in UK firms, Management Decision, 37(5), 475-464.

Leuz, C., Nanda, D. and Wysocki P. D. (2003). Earnings management and investor protection: An international comparison, Journal of Financial Economics, 69(3), 505-527

Lin, J. , Li, J. and Yang, J. (2006). The Effect of Audit Committee Performance on Earnings Quality. Managerial Auditing Journal, 21(9), 921-933.

Lin, J. W. and Hwang, M. I. (2010). Audit Quality, Corporate Governance, and Earnings Management: A Meta-Analysis, International Journal of Auditing, 14(1), 57-77.

Lin J. W., Kang G. and Roline A. (2009). The effects of the Blue Ribbon Committee and the Sarbanes Oxley Act of 2002 on the characteristics of the audit committees and the board of directors, Advances in Accounting, Finance and Economics, 2(1), 54-70.

Menon, K. and Williams, J. D. (1994). The use of audit committees for monitoring, Journal of Accounting and Public Policy, 13(2), 121-139.

Metawee, A., (2013). The relationship between characteristics of audit committee, board of 


\section{I Macrothink}

International Journal of Accounting and Financial Reporting ISSN 2162-3082

directors and level of earning management, Evidence from Egypt, Journal of International Business and Finance, Plymouth Business School, UK, January.

Naiker, V. and D. Sharma (2009). Former CPA Partners on the Audit Committee and Internal Control Deficiencies, The Accounting Review, 84(2), 559-587.

Nelson S. P. and Devi S. (2013). Audit committee experts and earnings quality, Corporate Governance: The international journal of business in society, 13(4), 335-351

Park, Y. W., and Shin, H. H. (2004). Board composition and earnings management in Canada, Journal of Corporate Finance, 10(3), 431-457.

Pergola, T. M. (2005). Management entrenchment: Can it negate the effectiveness of recently legislated governance reform? Journal of American Academy of Business, 6(2), 177-184.

Persons, O. S. (2009). Audit committee characteristics and earlier voluntary ethics disclosure among fraud and no-fraud firms. International Journal of Disclosure and Governance, 6(4), 284-297.

Pincus, K., Rusbarsky, M., Wong, J. (1989). Voluntary formation of corporate audit committees among NASDAQ firms. Journal of Accounting and Public Policy, 8(4), 239265.

Pucheta-Martinez, M.C. and Fuentes, C.D. (2007). The impact of audit committee characteristics on the enhancement of the quality of financial reporting: An empirical study in the Spanish context, Corporate Governance: An International Review, 15, 1394-412.

Sarbanes-Oxley Act. (2002). 107th Congress of the United States of America. Washington DC.

Sharma V. D. and Kuang C. (2014). Voluntary Audit Committee Characteristics, Incentives, and Aggressive Earnings Management: Evidence from New Zealand, International Journal of Auditing, 18, 76-89.

Soliman, M. M. and Ragab, A. A. (2014). Audit Committee Effectiveness, Audit Quality and Earnings Management: An Empirical Study of the Listed Companies in Egypt, Research Journal of Finance and Accounting, 5(2), 155-166.

Vafeas, N. (2005). Audit committees, boards, and the quality of reported earnings, Contemporary Accounting Research, 22(4), 1093-1122.

Watts, R. L., \& Zimmerman, J. L. (1986). Positive Accounting Theory. Retrieved from http://papers.ssrn.com/abstract $=928677$

Waweru, N. M. and Riro, G. K. (2013). Corporate Governance, Firm Characteristics and Earnings Management in an Emerging Economy, Journal of Applied Management Accounting Research, 11(1), 43.

Xie, B., Davidson, W.N. and DaDalt, P.J. (2003). Earnings management and corporate governance: the roles of the board and the audit committee, Journal of Corporate Finance, 9, 


\section{Macrothink \\ International Journal of Accounting and Financial Reporting \\ ISSN 2162-3082 2017, Vol. 7, No. 1}

295-316.

Yang, J. and Krishnan, J. (2005). Audit committees and quarterly earnings management, International Journal of Auditing, 9(3), 201-209.

Zhou, J., and Elder, R. (2003). Audit firm size, industry specialization and earnings management by initial public offering firms. Working Paper. Syracuse University, Syracuse, NY and SUNY-Binghamton, Binghamton, NY.

\section{Copyright Disclaimer}

Copyright for this article is retained by the author(s), with first publication rights granted to the journal.

This is an open-access article distributed under the terms and conditions of the Creative Commons Attribution license (http://creativecommons.org/licenses/by/3.0/). 